\title{
4 Metaphysics
}

\subsection{The Beautiful}

\subsubsection{Perfection}

Baumgarten discovers not just the laws of sensate cognition but those of both sensate cognition and sensate desire, which are intrinsically tied together at the dark ground of the soul, where one would usually expect "the other" of reason. Moreover, he uncovers these laws in the poetic passages of literary texts, whose structure and functions he analyzes in the Meditationes. In analyzing literary discourse as perfect sensate discourse (oratio sensitiva perfecta), he becomes attentive to the metaphysical capacities of literature. Within the scope of this analysis, sensate cognition turns out to be aesthetic cognition. Baumgarten's literary epistemology thus encompasses more than just rhetorical, semiotic, and poetological applications of his psychology. His epistemology also leads to questions about being, which belong to ontology; about the world, which belong to cosmology; and about God, which belong to natural theology. In his Kollegium, Baumgarten boils aesthetics down to its essence: "One could thus call aesthetics, due to some similarity, the metaphysics of beauty" (KOLL §1; so könnte man die Ästhetik nach einiger Ähnlichkeit die Metaphysik des Schönen nennen). "For the world of the senses is," as Gadamer formulates it, "not mere nothingness and darkness but the outflowing and reflection of truth." Today, anchoring literature in metaphysics is generally considered ideologically dubious, but Baumgarten's analogical method alone clears him of all suspicion. ${ }^{2}$ He does not become ensnared in the ideological traps that the metaphysics of art falls into at the end of the eighteenth century. This is in part because his aesthetics pursues what Carsten Zelle refers to as "paralogical objectives,"3 meaning that in the Aesthetica, the metaphysical attributes of perfection "have all already appeared in the guise of poetology or aesthetics before the concept of truth is theoretically treated." ${ }^{\prime 4}$ In other words, Baumgarten continues to transfer his theoretical concepts from one discipline to another. The point is not, however, that

1 Hans-Georg Gadamer, Truth and Method, ed. Garrett Barden and John Cumming (New York: Crossroad, 1975), 66.

2 See 2.2 Analogy.

3 Carsten Zelle, Die doppelte Ästhetik der Moderne: Revisionen des Schönen von Boileau bis Nietzsche (Stuttgart: J. B. Metzler, 1995), 70.

4 Scheer, Einführung in die philosophische Ästhetik, 70.

Ә OpenAccess. () 2020 Frauke Berndt, published by De Gruyter. (cc) BY-NC-ND This work is licensed under the Creative Commons Attribution-NonCommercial-NoDerivatives 4.0 License. 
he develops a typology and metaphorology of truth in the Aesthetica; rather, it is that he confronts the beauty of literature with its sheer materiality, with the real. His investigation into the beauty of literature thus reveals itself to be an Urszene of the modern metaphysics of media.

Literature and beauty pivot around the concept of perfectio. What qualifies as completeness in rhetoric is perfection in metaphysics. In the Meditationes, this concept marks the difference between poetics and rhetoric since literature, in contrast to sensate discourse more generally, strives toward perfection:" "General rhetoric may be defined as the science which treats generally of unperfected presentation of sensate representations, and general poetics as the science which treats generally of the perfected presentation of sensate representations" (MED § 117; Iam quum perfecte hoc fieri possit \& imperfecte, hoc doceret RHETORICA GENERALIS scientia de imperfecte repraesentationes sensitivas proponendo in genere, \& illud POETICA GENERALIS scientia de perfecte proponendo repraesentationes sensitivas in genere; see also MET §533). Designating a discourse as literature presumes its perfection in a metaphysical sense, and only imperfect sensate discourse can be the object of descriptive rhetoric (see KOLL § 24), which is a historical discipline for analyzing a series of given examples. Describing perfect sensate discourse therefore requires a different method and a different discipline. In the Meditationes, the science of perfect sensate discourse is called poetics, and in the first edition of the Metaphysica from 1739, Baumgarten expands its scope to all forms of art: "The science of cognizing and presenting sensately is AESTHETICS, the science of sensate meditation and discourse aiming either for lesser perfection, RHETORIC, or greater perfection, UNIVERSAL POETICS” (MET1 § 533; Scientia sensitive cognoscendi et proponendi est AESTHETICA, meditationis et orationis sensitivae vel minorem intendens perfectionem, RHETORICA, vel maiorem POETICA UNIVERSALIS). In considering the Meditationes and the Aesthetica together, my contention is that the Aesthetica realizes precisely such a universal poetics by elaborating a holistic theory of literature.

In the Aesthetica, perfection in the realm of aesthetics is defined as beauty: "The goal of aesthetics is the perfection of sensate cognition as such ( $\S 1)$. This, however, is beauty (Metaphysica $\S \S 521,662$ )" (AE $\S 14$; Aesthetices finis est perfectio cognitionis sensitivae, qua talis, §. 1. Haec autem est pulcritudo, Metaphysic. §. 521, 662). This marks the crossroads where the discourses of beauty and

5 See 3.4.1 Complexity. 
literature meet. ${ }^{6}$ Baumgarten cites Shaftesbury's Sensus communis (1709) to justify associating truth, beauty, and literature (see $\mathrm{AE} \S 556) .{ }^{7}$ In Baumgarten, beauty does not just partially overlap with literature, as Kant later proposes in the Kritik der Urteilskraft when he refers to metaphorically produced beauty as

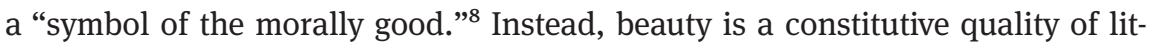
erature, which differentiates perfect sensate cognition from all other forms of sensate cognition. With his art of beautiful thinking (ars pulcre cogitandi), Baumgarten thus takes up a provocatively anachronistic position in the contemporaneous European discourses on beauty and art.

Whereas Bouhours and Jean-Baptiste Dubos, who both influenced Baumgarten, subject beauty to the sensus communis - and that means to the public's tastes - Baumgarten does not want to have anything to do with such democratic half measures. In the Kollegium, he argues that the well-known French treatises oriented toward the so-called artes cannot "exhaust" (KOLL § 1; erschöpfen) the problem of beauty. For he is not concerned with being moved by beauty but rather with the truth of beauty. Under this metaphysical premise, Baumgarten counters every "nescio quid" with the conviction that one has to be able to argue about taste (elegantia). He knows what is beautiful and what is not namely the imperfect, which for him is ugly: "and the imperfection of sensate cognition as such is to be avoided ( $§ 1)$. This, however, is ugliness (Metaphysica $\S \S 521,662$ )" (AE § 14; et cavenda eiusdem, qua talis, imperfectio, §. 1. Haec autem est deformitas, Metaphysic. §. 521, 662).

In the Kollegium, Baumgarten confirms that the perfection of cognition in general is the criterion for aesthetics in particular: "Aesthetics will have to have the perfection that cognition in general must have if it is to be perfect" (KOLL § 22; Die Ästhetik wird die Vollkommenheit haben müssen, die die Erkenntnis überhaupt haben muß, wann sie vollkommen sein soll). In the course of his reflections, he ties this demand for perfection back to confusio, the first function of the structure of literary discourse, by equating perfection with the abundance of marks. He even arithmetically calculates beauty through its degrees of perfection:

\footnotetext{
6 See Joachim Jacob, Die Schönheit der Literatur: Zur Geschichte eines Problems von Gorgias bis Max Bense (Tübingen: Max Niemeyer, 2007).

7 See Third Earl of Shaftesbury (Anthony Ashley Cooper), "Sensus Communis, an Essay on the Freedom of Wit and Humour in a Letter to a Friend," in Characteristics of Men, Manners, Opinions, Times, ed. Lawrence E. Klein (Cambridge: Cambridge University Press, 1999), 65.

8 Kant, Critique of the Power of Judgment, $\S 59$.
} 
Suppose I were thinking perfectly well in the low manner of thinking $=10$ [perfections], in the middle manner of thinking $=100$ [perfections], in the sublime manner of thinking I should reach 1000 [perfections], but I only reached them -100 [perfections] and -10 [perfections], then I would only have [890] perfections, which in all their mistakes would be, however, greater than the 100 perfections and the 10 perfections that I would have reached without mistakes in the other manners of thinking.

Gesetzt, ich dächte in der niedrigen Denkungsart $=10^{\circ}$ vollkommen gut, in der mittleren $=100^{\circ}$, in der Erhabenen sollte ich $1000^{\circ}$ erlangen, ich erlangte sie aber nur $-100^{\circ}$ und $-10^{\circ}$, so hätte ich nur $89^{\circ}$ Vollkommenheiten, die aber bei allen ihren Fehlern doch noch größer wären als jene 100 und als jene 10 Vollkommenheiten, die ich ohne Fehler in den anderen Denkungsarten erlanget hätte. (KOLL § 210)

Both the perfection of every cognition (perfectio omnis cognitionis) and, analogously, the beauty of sensate cognition (pulcritudo cognitionis sensitivae) are measured using the same rhetorical categories of style: abundance, greatness, truth, clarity, certitude, and life. ${ }^{9}$ With this analogy, Baumgarten presupposes, of course, a universal concept of beauty (pulcritudo universalis). Based on this concept, he opens, as Franke explains, a "discussion about the beauty of art within a field of problems" "that Kant then delimits terminologically through defining, on the one hand - teleologically justified - natural beauty and, on the other, artistic beauty." ${ }^{10}$ In Baumgarten, this categorical division between natural and artistic beauty does not exist. The universal beauty of sensate cognition (pulcritudo sensitivae cognitionis universalis) is therefore measured like the particular beauty of singular phenomena using the same six categories of style. As Scheer puts it, the ontological predicates of being are made in the Aesthetica into conditions for the existence of beauty. ${ }^{11}$

In part 1 of the Metaphysica on ontology (ontologia), Baumgarten accordingly grounds beauty in the three logical principles: the principle of contradiction, the principle of ground, and the principle of sufficient ground, which he then transfers to the Aesthetica (see AE $\S 426$ ). ${ }^{12}$ But instead of endorsing Benedetto Croce's position that this Leibnizian inheritance demonstrates the antiquated-

9 See 2.2 Analogy.

10 Franke, Kunst als Erkenntnis, 79.

11 See Scheer, Einführung in die philosophische Ästhetik, 70.

12 See Hans Carl Finsen, "Evidenz und Wirkung im ästhetischen Werk Baumgartens: Texttheorie zwischen Philosophie und Rhetorik," Deutsche Vierteljahrsschrift für Literaturwissenschaft und Geistesgeschichte 70.2 (1996): 202. 
ness of the Aesthetica, ${ }^{13}$ I will show that Baumgarten's ontology can shed new light on central concepts in his literary epistemology, ${ }^{14}$ in particular on his narratology, which I will discuss in chapter 5. In his ontology, he lists six predicates of being that are universally valid:

\author{
Section I: The possible (possibile) \\ Section II: The connected (connectum) \\ Section III: A being (ens) \\ Section IIII: The one (unum) \\ Sections V-VI: The true (verum) \\ Section VII: The perfect (perfectum)
}

In the following, I will discuss the three predicates of being italicized above; I will address the true later in this chapter ${ }^{15}$ and the possible in the context of his theory of fiction. ${ }^{16}$

In section 2 on the connected (connectum), Baumgarten adds another ontological justification for the structure of literary discourse to the three logical principles; this justification consists in the linking of the manifold elements or marks of an object. ${ }^{17}$ The series A, B, C thereby becomes a logical series: "The ground A of ground $\mathrm{B}$ is the ground of the consequence $\mathrm{C}$. From the ground of $\mathrm{B}$, it is possible to know why C is (§23); hence, A is the ground of C (\$14)" (MET § 25; Ratio A rationis $\mathrm{B}$, est ratio rationati $\mathrm{C}$. Ex ratione $\tau 8 \mathrm{~B}$ cognosci potest, cur $\mathrm{C}$ sit, §. 23. hinc A est ratio $\tau 8 \mathrm{C}$. $\S$. 14; see also MET $\S 33$ ). In section 7 on the perfect (perfectum), Baumgarten defines precisely this linking as the agreement (consensus) of all elements within a structure: "If several things taken together constitute the sufficient ground of a single thing, they AGREE. The agreement itself is PERFECTION, and the one thing in which there is agreement is the DETERMINING GROUND OF PERFECTION (the focus of the perfection)" (MET §94; Si plura simul sumta unius rationem sufficientem constituunt, CONSENTIUNT, consensus ipse est PERFECTIO, et unum, in quod consentitur, RATIO PERFECTIONIS DETERMINANS (focus perfectionis)). This definition culminates in the concept of

13 See Benedetto Croce, Storia dell'estetica per saggi (Bari: Gius. Laterza \& Figli, 1942), 93-122; Croce, "The Aesthetica of Baumgarten," in Philosophy, Poetry, History: An Anthology of Essays, trans. Cecil Sprigge (London: Oxford University Press, 1966), 427-450.

14 See 3 Epistemology. See also Angelica Nuzzo, "Determination, Determinability, and the Structure of Ens: Baumgarten's Ontology and Beyond,” in Fugate and Hymers, Baumgarten and Kant on Metaphysics, 23-41.

15 See 4.1.2 Truth.

16 See 5.3.1 Possibility.

17 See 3.4 Poetics. 
a rule-bound structure: "Therefore, in perfection there is order (§78) and common rules of perfection (§86)" (MET § 95; ergo est in perfectione ordo, §. 78. et communes perfectionis regulae, §. 86). Since rhetorical figures and tropes prescribe the rules of perfection in the Meditationes, rhetorical and metaphysical perfection coincide.

In the Metaphysica, perfection is closely accompanied by the question of how the parts of a structure relate to a composite (compositum) whole. Whereas in section 4 on the one (unum), Baumgarten engages with this problem from a philosophical perspective, the Aesthetica is concerned with how elements relate to each other to form a unity in the structure of literary discourse. To put this ontological principle in a nutshell, a lot must become one for something to be not only quantitatively complete but also qualitatively perfect: "The universal beauty of sensate cognition will be (§ 14) (1) the agreement of thoughts [...] among themselves upon a single thing that is a phenomenon (§ 14; Metaphysica $\S 662)$ )" (AE $\S 18$; Pulcritudo cognitionis sensitivae erit universalis, §. 14. 1) consensus cogitationum [...] inter se ad unum, qui phaenomenon sit, §. 14. Metaphysic. §. 662). In a syntactic analysis of this passage, Schweizer convincingly argues that the “masculine 'qui,' which begins the relative clause, can only refer back to 'consensus.' The representations thus do not, as the 'ad' in the expression 'ad unum' at first leads one to expect, refer to something beyond themselves; rather, the unity that their 'agreement' is based on is equated with the phenomenon itself." ${ }^{18}$ In his translation of the fourteenth paragraph - "[a]esthetices finis est perfectio cognitionis sensitivae qua talis" - Haverkamp even emphasizes that the apposition "qua talis" (as such) refers to "perfectio" and not to the genitive modifier "cognitionis sensitivae."19 In this way, the grammar completes a self-reflexive turn with regard to beauty. ${ }^{20}$ Both perfection in paragraph 14 and unity in paragraph 18 are set free from heteronomous points of reference (God, world, nature) because the elements of sensate cognition are linked among themselves (inter se), which encompasses both the relation of elements to one another (determinationes internae) and their relation to other objects (determinationes externae; see $\mathrm{AE} \S$ 439). This allows Baumgarten to liberate beauty both from its task of imitating the world (mimesis) ${ }^{21}$ and from its duty to serve other systems like religion or morality. We have thus entered the realm of modern poiesis in its emphatic sense.

18 Schweizer, Ästhetik als Philosophie der sinnlichen Erkenntnis, 38-39.

19 See Haverkamp, "Wie die Morgenröthe," $15 \mathrm{n} 23$.

20 See Finsen, "Evidenz und Wirkung im ästhetischen Werk Baumgartens," 211.

21 See 5.3.2 Probability. 
Yet between the parts and the whole of the perfect order there arises an enormous tension, indeed, a structural contradiction, which Baumgarten resolves in the Aesthetica in the sections on aesthetic abundance (ubertas aesthetica). There he posits that all rhetorical figures and tropes should strive for "copiousness, profusion, multitude, riches, and wealth” (AE § 115; copia, abundantia, multitudo, divitiae, opes). In these sections, he particularly exploits Pseudo-Longinus's On the Sublime by relying, like Kant, on superlatives to describe the sublime. Here again, the most important thing is the abundance of marks, which distinguishes the sublime from the other types of style: "Thus, according to this scale of intensity, the most beautiful argument and figure will be one that at once makes the cognition of something else [...] richer and weightier and truer and clearer and more certain and more ardent (§ 22)" (AE § 142; Erit itaque secundum hanc intensionis scalam argumentum et figura pulcerrima, quae cognitionem et locupletiorem, et graviorem et veriorem et clariorem et certiorem et ardentiorem alterius [...] simul efficiant, §. 22).

As Schweizer explains, the concept ubertas "anticipates on the level of rhetorical instruction what is called 'metaphysical' and at the same time 'real' and 'material' truth in the context of the epistemological questions" (see AE § 424). He continues: "The 'abundance' of the manifest world cannot be even approximately grasped with either logical cognition or aesthetic cognition; it transcends all cognitive possibilities and appears on the level of the epistemological questions as a 'metaphysical' horizon of truth"22 such that "the rhetorical concept of 'abundance' is only used here as a symbol for the abundance of manifest reality in general."23

Yet in these same sections on aesthetic abundance (ubertas aesthetica), Baumgarten surprisingly demands a well-rounded brevity (brevitas rotunda), which he develops based on Cicero's qualities of style. He already claims in the Meditationes that "it is poetic to omit certain details and more remote connections" (MED § 76; quaedam determinantia \& remotius connexa omittere poeticum): "By intrinsically or absolutely brief discourse we mean that which has nothing in it that could be left out without loss of a degree of perfection. Such brevity, since it is proper to every discourse, is also proper to a poem, § 9” (MED §74; INTRINSECE sive ABSOLUTE BREVIS est ORATIO, cui nihil inest, quod salvo perfectionis gradu abesse posset. Talis brevitas, quum sit omnis orationis, est etiam poematis §. 9). Here Baumgarten takes up the classical oratorical ideal of brevity and combines it with the reflexive figure of the circle, a

22 Schweizer, Ästhetik als Philosophie der sinnlichen Erkenntnis, 48.

23 Schweizer, Ästhetik als Philosophie der sinnlichen Erkenntnis, 47. 
symbol of perfection in the Neoplatonic tradition. To quote again from Schweizer, "The concept of 'brevitas' points, in contrast, to the individual act of sensate cognition and representation, to 'intuition,' which always only captures - visually speaking - a 'round something' in the fluctuating abundance of phenomena, whether it has to do with poetic, rhetorical expression or purely receptive acts of cognition."24

Aesthetic cognition thus has to "obtain at the same time both a pleasing round brevity (sections XIII-XIV) and beautiful coherence (§ 437)” (AE § 439: et placentem simul rotundam illam brevitatem S. XIII. XIV. et pulcram obtinebis cohaerentiam, §. 437): "We may refer to every kind of thinking beautifully as seemly brevity ( $§ 160)$, that full and replete brevity (§ 158), not lacking, without gaps (§ 159), nevertheless frugal and sober (§ 164), not luxuriant or disreputable (§ 165), in a word, ROUND BREVITY” (AE § 166; Brevitatem omne pulcre cogitandi genus decentem, §. 160, plenam illam et refertam, §. 158, non mancam, non hiulcam, §. 159. parcam tamen ac sobriam, §. 164, non luxuriantem aut maculosam, §. 165. uno nomine ROTUNDAM BREVITATEM dicere liceat; see also AE $\S 657)$. Only this well-rounded brevity transfers the infinite curvature of the metaphysical line of beauty onto the formal conditions of literature in a structurally analogous way, which induces Baumgarten to a comparison with geodesy: "Just as the horizon appears now wider, now narrower in geography, so can my aesthetic horizon be contracted or broadened" (AE § 149; Sicut in geographicis horizon apparens, nunc latior est, nunc angustior, ita meus horizon aestheticus potest contrahi, potest dilatari). The horizon is curved as far as necessary to grasp the limitless aspects of such a unique object in its well-rounded unity (see AE § 561).

In rhetoric, both abundance and brevity are quantitatively measured either by the number of arguments (using the spatial form of intuition) or by the duration of a speech (using the temporal form of intuition). Is it sufficient to simply transform quantity into quality for the metaphysics of beauty? Since Baumgarten refrains from any concrete comment about the point at which beautiful brevity turns into ugly length, a different model than quantitative measurement appears conceivable, and I am, indeed, of the opinion that the double unity of abundance and brevity follows a different logic when Baumgarten deploys it as a model for beauty. In this model, determining abundance and brevity is not simply a matter of calculating more or fewer links. With aesthetic abundance, he assigns an eccentricity to the structure of literary discourse, and with brevity he

24 Schweizer, Ästhetik als Philosophie der sinnlichen Erkenntnis, 48. 
places a concentricity at its side; without both of them, literature cannot be beautiful.

This model leads back again to rhetorical figures, the matrix of literature in Baumgarten's theory. Eccentricity and concentricity define the two sides of figures. This understanding of figures is based on the appetitive faculties. The sensate will, which Baumgarten conceptualizes in his psychology, defines the performative function of the structure of literary discourse in the context of his poetics. It is this function, which plays out sensate desire, that sets literature in motion. Every figure is performative since it can be conceived as a series (abundance). ${ }^{25}$ Figures are then also eccentric since the first element of a figure - which has by definition at least two positions - desires the second, the second the third, and so forth, without this open structure ever arriving at the goal of this desire. But we can also think of a figure as a circle (brevity). Figures are concentric since their elements aim to arrange each other in a circle. In that closed form, all the elements have the same distance from the center of the circle.

The eccentricity and concentricity of literature make it a self-reflexive entity and produce, through the opposing movements, the ambiguity of literature. So far I have referred to the ambiguity of aesthetics to emphasize that Baumgarten's new science consists in both epistemology and media theory, but the concept of ambiguity also applies to the structure of literary discourse itself. Its "ambiguity is not a contingent but a constitutive dimension."26 The ambiguity of an infinite finitude or a limited limitlessness positions beauty in an unresolvable tension between openness and closure. Achieved through the lower cognitive faculties, the beautiful remains "tied to a particular place and to a particular time"; ${ }^{27}$ the desire for beauty is a never-ending process, kept in motion in literature by the difference from the absolute. The tension between an existing form, on the one hand, and such an ambiguous beauty, on the other, culminates in the exclusion of sensation and perfection. In this context, one should once again recall the matrix of literature, the rhetorical figure. ${ }^{28}$ Figures are structurally characterized by how they make two out of one in the repetition of their elements. In Baumgarten's theory of literature, figures thus form not only the core of poetics but also the core of metaphysics. So when Cassirer writes that "the beautiful is essentially and necessarily a symbol because, and to the extent that, it is split

25 See 3.1.2 Desire; 3.4.3 Performativity.

26 Frauke Berndt and Klaus Sachs-Hombach, "Dimensions of Constitutive Ambiguity," in Ambiguity: Language and Communication, ed. Susanne Winkler (Berlin: Walter de Gruyter, 2015), 273.

27 Schweizer, Ästhetik als Philosophie der sinnlichen Erkenntnis, 44.

28 See 3.4.1 Complexity. 
within itself, because it is always and everywhere unity and double,"29 he seems to be thinking of Baumgarten.

\subsubsection{Truth}

Baumgarten's metaphysics of beauty creates the riddle of this aesthetics since it leaves open not only the relation between perfection and sensate cognition but also the relation between its subjective and objective aspects. ${ }^{30}$ Is he articulating a theory of aesthetic experience or an ontology of beauty ${ }^{31}$ As Scheer demonstrates, the answer is both: "This twofold site of beauty in Baumgarten makes this thinker a transitionary figure in aesthetics. Beauty is anchored objectively (in traditional ontology) and subjectively (in the functions of sensation)." 32 While in his Kritik der Urteilskraft, Kant recognizes "not the perfection of any object" but rather nothing "but the subjective purposiveness of representations in the mind of the beholder," 33 in Baumgarten, ontology and aesthetics are still two sides of the same coin: one side concerns the beauty of the object, the other the judgment of sensate taste (see MET $\S 640$ ). The necessity of such a doubling lies in the ambiguity of aesthetics itself, which he brings into play with the doubling of cognition and representation (Darstellung). ${ }^{34}$ Once this doubling is recognized, the strategy no longer seems problematic - except, apparently, to Baumgarten, who attempts to penetrate the beautiful surface of literature to its true depths. In the Aesthetica, this leads to the sections on aesthetic truth (veritas aesthetica), where the concept of beauty cedes all its functions to the concept of aesthetic truth, ${ }^{35}$ and aesthetic truth becomes the focus of the philosopher's enormous efforts to resolve the ambiguity of aesthetics.

29 Ernst Cassirer, “The Problem of the Symbol and Its Place in the System of Philosophy (1927),” in The Warburg Years, 255.

30 See Anna-Maria C. Bartsch, Form und Formalismus: Stationen der Ästhetik bei Baumgarten, Kant und Zimmermann (Würzburg: Königshausen \& Neumann, 2017), 35-91.

31 See Franke, Kunst als Erkenntnis, 89.

32 Scheer, Einführung in die philosophische Ästhetik, 78. See also Alexander Aichele, "Wahrheit - Gewissheit - Wirklichkeit: Die systematische Ausrichtung von A. G. Baumgartens Philosophie," in Aichele and Mirbach, "Alexander Gottlieb Baumgarten," 13-36; Armin Emmel, "Logische, ästhetische und metaphysische Wahrheit bei Alexander Gottlieb Baumgarten,” in Identität - Logik - Kritik: Festschrift für Ulrich Pardey zum 65. Geburtstag, ed. Benedikt Fait and Daniela Zumpf (Berlin: LIT, 2014), 211-242.

33 Kant, Critique of the Power of Judgment, § 15.

34 See 2.1 Ambiguity.

35 See Schweizer, Ästhetik als Philosophie der sinnlichen Erkenntnis, 40. 
In the Kollegium, Baumgarten uses an illustration of his typology of truth to discuss the traditional metaphysical premises of truth. He includes his own new position in this schema with yet another etymologically created neologism: veritas aestheticologica (Fig. 1: KOLL § 424).

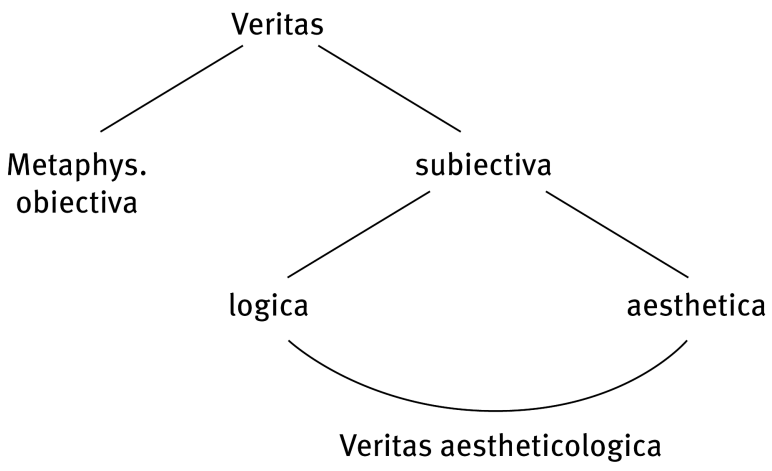

Fig. 1

The opposition of metaphysica obiectiva and subiectiva concerns the relationship of objective and subjective aesthetics. While objective, real, or material truth (veritas realis, materialis) is based on the ontological unity of the manifold, ${ }^{36}$ subjective truth refers to a concept of the subject similar to the one used in rationalist epistemology. Subjective truth can therefore be called mental truth (veritas mentalis) or the logical truth of affinity, correspondence, and conformity (veritas logica afficientiae, correspondentiae et conformitatis) if it is achieved through the higher cognitive faculties; subjective truth is aesthetic truth if it is achieved through the lower cognitive faculties. There are no universal concepts (universalia) for knowing aesthetic truths but rather only singular terms (individua). ${ }^{37}$ The more particular something is, the more complex and true it is, too, such that the singular truth (veritas singularis) of perceptions increases from the genus to the species to the individual: "the first [perception] is of the true, the second is of the truer, and the third is of the truest (§440)" (AE $\S 441$; Prima veri, secunda verioris, tertia verissimi. §. 440). Given this presupposition, Baumgarten is faced with the problem of justifying aesthetic truth with regard to logical truth. The easiest way for him to do so is by referring to the dif-

36 See 4.1.1 Perfection; 4.2 The Real.

37 See 3.4.1 Complexity. 
ferent ratios for mixing aesthetic and logical truth. On the one hand, what is aesthetically true is often also logically true (see AE § 427); on the other, aesthetic parts contribute to a logically true whole (see $\mathrm{AE} \S 428$ ).

Aestheticological truth is further differentiated into general and singular aestheticological truth (see $\mathrm{AE} \S 440$ ), depending on whether it refers to universal concepts or singular terms:

It will be preferable, however, to repeat the degrees of aestheticological truth somewhat more deeply for more serious supporters [of aesthetics]. The smallest aestheticological truth is the smallest perception of the smallest metaphysical truth. Hence (1) the richer, (2) the greater and worthier, (3) the more precise, (4) the clearer and more distinct, (5) the more certain and firmer, (6) the more fiery the perception of an object is, (7) the more things the object itself encompasses, (8) the greater and weightier the things it encompasses, (9) the stronger the standards according to which it encompasses, (10) the more consistent the things it encompasses, so much greater is the aestheticological truth (§ 437; Metaphysica § 184).

Praestabit autem severioribus veritatis fautoribus aestheticologicae gradus altius nonnihil repetere. Minima est minima perceptio veritatis metaphysicae minimae. Hinc 1) quo uberior, 2) quo maior et dignior, 3) quo exactior, 4) quo clarior et distinctior, 5) quo certior et solidior, 6) quo ardentior est perceptio obiecti, 7) quo hoc plura, 8) quo maiora ac graviora, 9) quo fortioribus regulis, 10) quo convenientiora complectitur, hoc maior est veritas aestheticologica, §. 437. M. §. 184. (AE § 556)

In this passage, Baumgarten switches - and this has escaped notice in the scholarship - to a theory of fiction in which he concretizes what is aesthetically or logically true in a poetic world. ${ }^{38}$ But since I would first like to remain on the abstract level of concepts before I take up this problem in chapter 5 on narratology, I will only discuss a brief example here. The cover of this book displays the painting Artus reitet from Dieter Asmus's Parzival-Zyklus (2011). In this painting, King Arthur and his armed entourage are riding through a field of giant poppies. The horses are logically true, and so is the historical background. The magnificent poppies are aesthetically true, as is the mythological background and the connotation of sleep and death, which makes the poppy a chthonic-maternal symbol in Arthur's rite of passage. By contrast, the proportions of the knights and poppies are logically and aesthetically false. Would this image not be a perfect emblem for Baumgarten's own adventure in facing poetry? But if we turn away for now from this theory of fiction to literature's linguistic nature, we can understand the relation of logical and aesthetic truth in a more general manner, since language has both logical and aesthetic aspects. Grammar is re-

38 See 5.3.1 Possibility. 
sponsible for the logical truth of literature; the pre-predicative phenomena of poetic passages, such as figurality, phonetics, and rhythm, are responsible for its aesthetic truth. ${ }^{39}$

The compound attribute aestheticologicus has to reconcile reason and sensation within subjective truth. Aestheticological truth is a kind of truth "in which aesthetic intuition and logical distinction are combined into a unity or [...] in which the difference between 'aesthetic' and 'logical' has not yet even become relevant." ${ }^{40}$ In any case, the difference between aesthetics and logic does not concern the hierarchy of reason and sensation or the different relations between the aesthetic and logical components of truth (see AE $\S \S 427-428$ ). It is rooted, rather, in the problem that aesthetic and logical truth must be oriented toward one and the same absolute: the logical truth of the whole (veritas totius logica). Baumgarten does not leave any room for doubt that aestheticological truth is always deficient in comparison to the highest form of truth, logical truth, which can only be intuited by God. Aestheticological truth is, by contrast, human and thus imperfect (see $\mathrm{AE} \S 57$ ).

In the end, Baumgarten is actually not interested in logical truth at all but only in aesthetic truth. In analyzing aestheticological truth, he is concerned with an indirect mode of truth only possible in aesthetic truth:

\begin{abstract}
We only note this: that truth, insomuch as it is intellectual, is not sought directly by the aesthetician; if it emerges indirectly out of many aesthetic truths or coincides with something that is aesthetically true, the rational aesthetician can congratulate himself on this (§38). Yet this is not what he was chiefly seeking (§ 423).

Hoc unum observamus, veritatem ab aesthetico, quatenus intellectualis est, non directo intendi, si per indirectum ex veritatibus aestheticis pluribus una prodeat, aut cum aesthetice vero coincidat, de illo sibi gratulari aestheticum rationalem, §. 38. neque tamen illud esse, quod nunc potissimum quaerebatur, §. 423. (AE § 428)
\end{abstract}

The concept aestheticologicus thus acts as a placeholder in the discourse on truth. The logical part of the concept provides temporary assistance and serves at the same time as a nod to the rationalist tradition, but its main purpose is to allow Baumgarten to proceed as quickly as possible to engaging with aesthetic truth:

Of the general aestheticological truths, the aesthetic ones are those that can - and they are aesthetic only insofar as they can - be represented sensately by the analogon of reason without losing their beauty (§§ 440,423), either manifestly and explicitly, or cryptically

39 See 4.2.1 Materiality.

40 Schweizer, Ästhetik als Philosophie der sinnlichen Erkenntnis, 42. 
in the omitted assertions of enthymemes, or in examples, in which, just as in concrete things, these abstract things are detected.

Veritatum aestheticologicarum generalium eae tantum aestheticae sunt, quae et quatenus analogo rationis, salva venustate, sensitive repraesentari possunt, §. 440, 423. vel manifesto, et explicite, vel cryptice in omissis enthymematum enunciationibus, vel in exemplis, in quibus, tanquam concretis, haec abstracta deprehendantur. (AE § 443)

With aestheticologicus, Baumgarten thus brings together metaphysics, epistemology, and rhetoric by positing that the sensate operations of the analogon of reason are responsible for producing aesthetic truth.

But this raises the question of how the indirect mode of aesthetic truth is consistent with the certain intuition of beauty, which is the only way it is available to cognition. The truth of literature is, according to Baumgarten, beautifully evident. In section 50 on aesthetic evidentia (evidentia aesthetica) - which belongs to the sections on aesthetic persuasion (persuasio aesthetica) - he therefore outlines the concept of an evidentia that is defined by the attributes aesthetica, bella, pulcra, or sensitiva. As I discussed above, evidentia plays an important role in Baumgarten's literary theory since it defines two of the three functions of the structure of literary discourse: opacity in the tradition of enargeia and performativity in the tradition of energeia..$^{41}$ But in addition to these rhetorically anchored concepts, evidence also has a metaphysical dimension, which is based on Cartesian logic. Baumgarten introduces evidence in the Metaphysica as follows: "The clearer, livelier, more distinct and more certain is knowledge, the greater it is. A PERCEPTION having the certitude of another as a corollary, and ITS POWER, is either PERSUASIVE or CONVINCING. Certain perspicuity is EVIDENCE” (MET $\S 531$; Quo clarior, quo vividior, quo distinctior, quo certior cognitio est, hoc maior est. PERCEPTIO certitudinem alterius habens pro corollario, \& VIS EIUS, est vel PERSUASORIA, vel CONVINCENS. Certa perspicuitas est EVIDENTIA).

In this context, Baumgarten first juxtaposes intellectual evidence and sensate evidentia and differentiates sensate certitude (certitudo sensitiva) through persuasion from rational certitude through conviction (convictio): "Sense certitude is PERSUASION, whereas intellectual certitude is CONVICTION" (MET $\S 531$; Certitudo sensitiva est PERSUASIO, intellectualis CONVICTIO). When he later defines evidentia in the Aesthetica, he reconfirms this difference between intellectual evidence and sensate evidentia, "which others call a demonstration for the eye, for the senses, and palpable, the analogue of an intellectually convincing demonstration" (AE § 847; quam alii demonstrationem ad oculum, ad

41 See 3.4.2 Opacity; 3.4.3 Performativity. 
sensus, et palpabilem dixerint, demonstrationis intellectualiter convincentis analogon). Such bella evidentia is immediately accessible and intuitive. That this definition of sensate evidentia is analogous to that of intellectual evidence once again reaffirms Baumgarten's analogical method:

\footnotetext{
However much more clearly, yet sensately so (§ 614), hence however much more vividly ( 619 ), however many more and greater truths are set up before the eyes of the mind by persuading your personal objects, so much greater will the persuasion be, and so much greater the evidentia that will accompany it (Metaphysica § 880).
}

Quo clarius, sensitive tamen, §. 614 hinc quo vividius, §. 619. quo plures, quo maiores veritates persuadendo sistuntur obiectis tuis personalibus ob oculos mentis: hoc maior erit persuasio, hoc maior eam comitabitur evidentia, M. §. 880. (AE § 853)

Campe argues that in addition to the tension between logic and rhetoric, Baumgarten repeats the "doubling of intuition and rhetoric" on the side of sensate evidentia by differentiating between visual figures in the sections on aesthetic light (lux aesthetica) and figures of intentionality in the sections on aesthetic persuasion (persuasio aesthetica). The former aim for a "certitude that is due to attention in the representation," and the latter for a "certitude that lies in the intention of the representation." ${ }^{42}$ Contrary to Campe, I think this differentiation has a different force, one that is mainly based on how Baumgarten distinguishes within evidentia between enargeia and energeia, and thus describes the function of opacity in the context of the cognitive faculties and the function of performativity in the context of the appetitive faculties.

With regard to literature, Baumgarten assigns opacity to the field of visuality and performativity to the field of affectivity. He accordingly differentiates between visual evidentia, which he discusses in the sections on aesthetic light (lux aesthetica), and affective evidentia, which he treats in the sections on aesthetic persuasion (persuasio aesthetica). Visual evidentia places something before the eyes of the mind, producing sensate perspicuity, while affective evidentia moves and touches. Of course, we cannot be certain about this differentiation, since Baumgarten abandoned the Aesthetica at this point and did not complete the sections on aesthetic persuasion (persuasio aesthetica) where he would have defined bella evidentia as affective evidentia; but I think he would have had to turn there to performative figures related to the voice. ${ }^{43}$

In any case, visual evidentia depends on the rhetorical figures and tropes responsible for sensate perspicuity. Especially the figures of allegory and descrip-

42 Campe, "Der Effekt der Form," 33. See 6.3.2 Parrhesia.

43 See 3.4.3 Performativity. 
tio prove to be particularly productive for metaphysics. In this respect, Campe offers insightful remarks on the origin and redeployment of descriptio: "When Baumgarten calls the perfection of the aesthetic object its complete determination, he constructs the fundamental concept framing the sensate cognition of aesthetics based on visual descriptio of baroque provenance. Nowhere is it clearer that rhetoric is absorbed into some of its concepts in the eighteenth century."44 Campe's suggestion that Baumgarten must have been reserving bella evidentia for the figures "that are not tropes, that is, for syntactic, tonal, and morphological figures, ${ }^{45}$ must, however, be rejected in light of my earlier analysis of figures and tropes, ${ }^{46}$ both of which induce bella evidentia. For the whole canon of style is responsible for both the visual and the affective evidentia of beauty.

\subsubsection{Twilight}

The search for truth leads into a fog (nebula; see AE § 451). It is a fog that results from the necessity of using metaphors instead of concepts in this philosophical context. By employing figures and tropes, Baumgarten's own discourse makes bella evidentia beautifully evident. And in total, the Aesthetica contains more sections on metaphorology than on the typology of truth. Altogether, this suggests that it would be productive to read some paragraphs of the Aesthetica located at the intersection between psychology, rhetoric, and metaphysics as literature - with just as much attention to their techniques of representation as to their propositional content. In particular, the epistemological metaphors of light running through the Aesthetica express what Baumgarten expects from the metaphysics of beauty. These metaphors culminate in the sections on aesthetic light (lux aesthetica).

Bella evidentia appears at “dawn” (KOLL § 7; Dämmerung). The truth of beauty is thereby measured against the logical ideal of reason, which shines brightly like the sun (sol; see AE $§ 616$ ). Baumgarten turns away from this rationalistic ideal and looks for the beautiful not in the bright sun but rather in the waning night, the realm of shadows. Especially in the third part of the Metaphysica on psychology (psychologia), he views darkness as the anthropological foundation of aesthetics: "There are obscure perceptions in the soul (§510). The collection of these perceptions is called the FOUNDATION OF THE SOUL"

44 Campe, "Vor Augen Stellen,” 209.

45 Campe, "Bella Evidentia,” 253.

46 See 3.4.2 Opacity. 
(MET § 511; Sunt in anima perceptiones obscurae, §. 510. Harum complexus FUNDUS ANIMAE dicitur). Dark or obscure representations are those that do not draw any distinct contours between marks but instead blur marks together: "Therefore, one who is confusedly thinking something represents some things obscurely" (MET § 510; Ergo confuse quid cogitans quaedam obscure repraesentat). ${ }^{47}$ Baumgarten draws a very clear correlation between the concepts confusus and obscurus, which means that nondistinct sensate representations belong to the realm of darkness (regnum tenebrarum), for which the lower cognitive faculty is responsible: "Hence the faculty of knowing something obscurely and confusedly, or indistinctly, is the INFERIOR COGNITIVE FACULTY. Therefore, my soul has an inferior cognitive faculty $(\S 57,216)$ )" (MET $\S 520$; Unde FACULTAS obscure confuseque seu indistincte aliquid cognoscendi COGNOSCITIVA INFERIOR est. Ergo anima mea habet facultatem cognoscitivam inferiorem, §. 57, 216; see also MET § 518).

This model literally paints things in black and white: here is the sphere of reason and light (perspicuitas, lux), and there the sphere of sensation and darkness (obscuritas, caligo). Although Baumgarten vindicates darkness with reference to nature (obscuritas naturae; see AE $\S 653$ ), he rejects it when he is concerned with literature "since the lack and opposite of clarity is obscurity" (AE $\S 631$; Defectus et oppositum lucis ac claritatis quum sit obscuritas). Whatever contains a flaw like that of darkness cannot be perfect or beautiful. He therefore repeatedly juxtaposes beautiful perspicuity (bella perspicuitas) with ugly darkness. So, unlike the models of the unconscious that build on Herder, Baumgarten's Aesthetica does not affirm irrational darkness. Instead, like Leibniz and Wolff, Baumgarten conceives of the dark processes of the soul from the perspective of the rational: ${ }^{48}$

Our soul is made in such a way (which one would not realize from the improvements in psychology) that an astonishing quantity of representations remain dark in its foundation but often reach a low degree of darkness and simultaneously latch onto the realm of clarity. [...] The realm of clarity and this field of dark representations, which moves somewhat toward the realm of clarity, together provide a broad field for the beautiful spirit.

Unsere Seele ist so beschaffen (welches man vor der Verbesserung der Psychologie nicht bemerkte), daß eine erstaunende Menge von Vorstellungen im Grunde derselben dunkel bleiben, daß sie aber oft zu einem geringen Grade der Dunkelheit gelangen und sich gleichsam an das Reich der Klarheit anhängen. [...] Das Reich der Klarheit und dieses Feld

47 See 3.4.1 Complexity. See also Frauke Berndt, "In the Twilight Zone: Ambiguity and Aesthetics in Baumgarten," in Amphibolie - Ambiguität - Ambivalenz, ed. Berndt and Stephan Kammer (Würzburg: Königshausen \& Neumann, 2009), 121-136.

48 See Adler, "Fundus Animae," 202. 
der dunklen Vorstellungen, das etwas an das Reich der Klarheit anrückt, geben zusammengenommen ein weites Feld für den schönen Geist. (KOLL § 80)

Since neither similarities nor differences can be made out in dark representations, completely dark sensate representations are incompatible with Baumgarten's theoretical presuppositions. He therefore suspects beauty to be somewhere between light and darkness, a transition that he not only characterizes as temporal but also as a spatially intermediate realm - a realm that opens up between the heavenly domain and the foundation of the soul:

Our opponents say that confusion is the mother of error; let us extend the metaphor; a mother cannot always give birth, so confusion also cannot always produce errors. In nature, it is not now night and then bright day follows immediately after, but rather there is a dawn in between them. So we do not immediately have the bright day of knowledge, but rather confusion comes in between as the dawn.

Unsere Gegner sagen, die Verwirrung ist die Mutter des Irrtums; lasset uns die Metapher fortsetzen; eine Mutter darf nicht immer gebären, so darf auch die Verwirrung nicht immer Irrtümer hervorbringen. In der Natur ist nicht jetzt Nacht, und dann folgt gleich heller Mittag, sondern es ist eine Dämmerung dazwischen. So haben wir nicht gleich hellen Mittag der Kenntnis, sondern die Verwirrung als die Dämmerung ist dazwischen. (KOLL § 7; see also MET § 511)

"Nature does not leap from obscurity into distinctiveness" (AE § 7; natura non facit saltum ex obscuritate in distinctionem). With this statement, Baumgarten justifies the metaphor of dawn, which stands for ambiguity. Yet such an ambiguity - an equivocality located between perspicuity and darkness, between clear explicitness and dark indeterminateness - could not have been his intention. If he had related aesthetic truth to logical truth using the times of day as a model and assigned a directional vector to this relationship - from the night through sunrise to midday (ex noctis per auroram meridies; see AE $\S 7$ ) - then such a model would represent the unavoidable end of aesthetics' autonomy from logic, since every sunrise would be a step on the path toward midday.

His defense of dawn with respect to midday therefore turns out to be somewhat complicated: "We also do not seek it [confusion] because it is confused but rather because it is vivid; let us give an example from theology: God seeks the sinner but not because he is a sinner" (KOLL $\S 7$; Wir suchen sie [die Verwirrung] auch nicht, weil sie verworren ist, sondern weil sie lebhaft ist; und dürfen wir ein Exempel aus der Theologie geben: Gott sucht den Sünder, aber nicht weil er ein Sünder ist). Dawn is thus not a particularly apt metaphor for bella evidentia, since the model of the times of day relates dawn and midday to one another in a temporal continuum. This model does not adequately represent beauty be- 
cause ambiguity is not a rhetorical vice but rather the most dignified aesthetic quality.

From an epistemological perspective, Baumgarten is well able to establish the autonomy of aesthetics from logic. Sensate representations are not distinct but confused, not obscure but clear, not intensively clear but extensively clear. These differentiations guide the light metaphors in the prolegomena of the Aesthetica. But in the sections on aesthetic light (lux aesthetica), they move away from a kind of provisional solution like dawn to a much more sophisticated model of light:

Section XXXVII: Aesthetic light (lux aesthetica)

Section XXXVIII: Aesthetic darkness (obscuritas aesthetica)

Section XXXVIIII: Aesthetic shadow (umbra aesthetica)

Section XXXX: The right dispensation of light and shadow (iusta lucis et umbrae dispensatio)

In this shading of aesthetic light, Baumgarten posits that the light and darkness of sensation are not located between the night and day of reason but are, instead, different from its light and darkness:

Since the lack and opposite of clarity is obscurity, but light and clarity are either sensitive or intellectual (section XXXVII), the ancients already distinguished quite rightly between obscurity kat' aisthesin [according to sensation] and obscurity kata noesin [according to intellection]. The thing and thought that, when it is to be perceived by the senses, does not have enough clarity, meaning extensive clarity, or aesthetic light, is obscure kat' aisthesin [according to sensation].

Defectus et oppositum lucis ac claritatis quum sit obscuritas, lux autem et claritas vel sen-

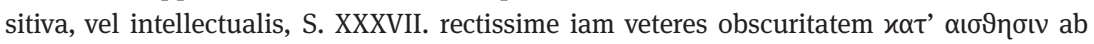
obscuritate $x \alpha \tau \alpha$ vonoıv distinxerunt. Res et cogitatio, quae sensitive percipienda non

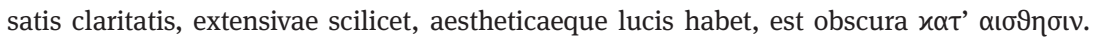
(AE § 631)

A different light than that of the sun of logic shines in the realm of aesthetics. Sensate light (lux sensitiva) does not shine less brightly than the sun but differently because it involves a kind of indirect illumination (see AE $\S 617$ ). This twilight does not lead from the domain of aesthetics into the domain of logic because the world of twilight is a different one than that of logic. This indirect light is suited to the specific structure of aesthetic cognition; it is the illumination technique of extensively clear representations, from which arises the opacity of literature. ${ }^{49}$

49 See 3.4.2 Opacity. 
Baumgarten differentiates in this indirectly produced light between absolute and relative aesthetic light. Whereas absolute light shines on the metaphysical goal of all cognition, aesthetic cognition takes place in relative light. It appears in the complex, opaque, and performative structure of literary discourse. This relative light strives toward a goal that it necessarily fails to meet (see AE § 617). In opposition to active luminosity, aesthetic light only passively reflects absolute light. This brilliance radiates from a body that does not glow itself but rather is only shined upon:

And so all aesthetic light you directly strive for will be the sensate perspicuity of things, the extension of clarity through the multitude of marks (§ 617), and indeed absolute, certainly comparative, the brilliance and splendor of vivid thoughts and matter (Metaphysica § 531).

Omnis itaque lux aesthetica, quam in rebus intendas directo, perspicuitas rerum erit sensitiva, claritatis per multitudinem notarum extensio, §. 617. etiam absoluta, comparativa vero vividarum cogitationum et materiae nitor ac splendor. M. §. 531. (AE § 618)

In an open appropriation of Quintilian's terms, ${ }^{50}$ Baumgarten introduces two types of beautiful cognition (cognitio pulcra): simple, clear, and distinct (genus dilucidum et perspicuum) on the one hand, and brilliant and splendid on the other (genus nitidum et splendidum; see AE §625). Only the second type possesses the splendor of beauty, with which he revives the medieval idea of beauty as splendor veritas; Hegel will later inherit this metaphor from Baumgarten. With complexity, brilliance increases less in intensity than in extensity and thereby reaches its splendor; for this, Baumgarten uses the attribute praegnans: ${ }^{51}$ "Pregnant perceptions (Metaphysica $\S 517$ ), and complex ones too (Metaphysica $\S 530$ ) if all else is equal, themselves shine more than those that are less complex, and can become arguments that are illustrative of the whole meditation they undertake (§730)" (AE §732; Perceptiones praegnantes, M. §. 517. et complexae, M. §. 530. et ipsae, caetera si fuerint paria, magis splendent, quam minus complexae, et totius, quam ingrediuntur, meditationis possunt argumenta fieri illustrantia, §. 730).

The differentiation between absolute and relative aesthetic light also finds its way into aesthetic darkness. If it is absolute, Baumgarten speaks pejoratively of aesthetic darkness; if it is relative, he speaks of aesthetic shadow, which he universally characterizes positively in contrast to darkness and pure night (nox; see AE § 634). He conceives of six rules for using the art of shading (ars

50 See Quint., Inst. 8.2-3.

51 See Gottfried Gabriel, "Baumgartens Begriff der 'perceptio praegnans' und seine systematische Bedeutung," in Aichele and Mirbach, "Alexander Gottlieb Baumgarten,” 61-71. 
obumbrandi), which playfully dips beauty into twilight by means of the appropriate illumination (see AE $\S \S 657-662$ ). With the relationship of absolute light and relative brightness, absolute darkness and relative shadows, he draws on a comparison that strongly associates bella evidentia with a deficiency. But it is a constitutive deficiency: like a painting that only becomes visible in the interplay of brightness and shadow, neither absolute light nor absolute darkness appear in literary texts (see AE $§ 635$ ). That is the result of Baumgarten's analysis of a poem by Catullus:

\begin{abstract}
It is true for all beauty just as for painting, provided that all things are conspicuous through the light we called absolute, that not all things but rather only certain things that are comparatively bright

[shine with a] face as bright as a flower in bud -

white parthenium blossom or

golden yellowish poppy. ${ }^{52}$ (Catull.)

Certain things are truly, are suitably clear, although whenever they are compared to brilliant and exceedingly illuminated things, they appear opaque, and at first glance they are judged coarse (§ 621). Not everything but many things shine elegantly in a poem (Hor.; § 625).
\end{abstract}

Verum in omni venustate generatim, sicut in pictura, modo sint omnia luce, quam absolutam diximus, conspicua, non omnia, sed quaedam tantum, comparative lucida

Ore floridulo nitent,

Alba parthenice velut,

Luteumve papaver, Cat.

quaedam sunt vere, sunt belle perspicua, quanquam, cum nitidis illis et admodum collustratis ubi comparentur, appareant opaca, quaeque primo obtutu iudicentur horrida, §. 621. Eleganter, non omnia, sed plura nitent in carmine. Hor. §. 625. (AE § 624)

The idea of uniform direct light does not do justice to beauty; what does, rather, is a play of reflected light arising from the quick oscillation of brightness and shadows. The literary text thus becomes a simulacrum - a will-o'-the-wisp whose luminosity flits back and forth.

While Baumgarten does not coin a special metaphor for this, Meier does so in the Anfangsgründe aller schönen Wissenschaften (1748). With the help of the metaphor of granularity, he explains the evidentia of pregnant concepts (conceptus praegnantes): "Such concepts, which are, as it were, pregnant, give rise to the granularity [das Körnichte] of our thoughts. As often as one thinks about them, one discovers something new in them that one had not perceived before, and one must speedily, so to speak, make an extensive commentary on them." 53

52 Quoted (with modification) from Gaius Valerius Catullus, The Poems of Catullus: A Bilingual Edition, trans. Peter Green (Berkeley: University of California Press, 2005), 61.186-188.

53 Meier, Anfangsgründe aller schönen Wissenschaften, vol. 1, §126. 
The metaphor of granularity also stands for the structure of literary discourse, which Baumgarten defines as a spatiotemporal composition. The entry on körnicht in the Grimm dictionary defines the word as meaning "made up of grains, in a granular form" and quotes, among others, a cosmological example: "the '..' shapes whose parts are strung together in a crystalline or granular manner. Humboldt kosm. 1, 165. frequently together with another adj. such as groszkörnicht, kleinkörnicht, grobkörnig, feinkörnig, vollkörnig, wahnkörnig etc."54 The attribute granular thus refers to a structure whose fragments variously refract light. In a certain way, bella evidentia also appears in a granular manner, that is, iridescently. Although Baumgarten never traveled and also does not qualify as a connoisseur of art, he is apparently well acquainted with the staging of light (light sources, light modeling, etc.) in landscape painting when he describes the truth of literature as analogous to the truth of a painted landscape (see AE § 624; indeed, the Aesthetica would go on to influence eighteenth-century visual art). ${ }^{55}$ There he is fascinated by the change between illuminated and unilluminated spots; and it is the relations that arise precisely through this contrast - and not, for example, the relations between what is depicted - that give rise to the effect of the "whole" image; the effect, mind you, and nothing more, since in its complexity, opacity, and performativity, literature always remains granular.

When Baumgarten finally comes to a model of bella evidentia, he finds it in the process of indirect illumination, which is just as different from the darkness of the fundus animae and the sunlight of reason as it is from the idea of becoming enlightened through a transition from darkness to light. Aesthetic light does not shine uniformly, nor do single points always glow and others never; instead, they shimmer in the permanent fluctuation of brightness and shadows. Neither the brightest spot nor the darkest point reveals the beauty of literature because literature must remain a thing of the twilight. The metaphors of light thus confirm the principle of ambiguity at the core of the metaphysics of beauty, which situates the order of perfection between abundance and brevity in a constitutive structural ambiguity. Baumgarten discovers that "unavoidable spin-off effect of a

54 Jacob Grimm and Wilhelm Grimm, Deutsches Wörterbuch (Leipzig: Hirzel, 1873), s.v. "körnicht." See also Johann Christoph Adelung, Grammatisch-kritisches Wörterbuch der Hochdeutschen Mundart, mit beständiger Vergleichung der übrigen Mundarten, besonders aber der Oberdeutschen, 2nd ed., vol. 2 (Leipzig: Johann Gottlob Immanuel Breitkopf, 1796), s.vv. "Körnicht," "Körnig."

55 See Andreas Jürgensen, "Der ästhetische Horizont: Baumgartens Ästhetik und Malerei um die Mitte des 18. Jahrhunderts” (Diss., Christian-Albrechts-Universität zu Kiel, 1993). 
superordinate tendency or evolution towards higher autoreferentiality" discernible in beauty, whose ambiguity is the signature of modernity. ${ }^{56}$

\subsection{The Real}

\subsubsection{Materiality}

The order of perfection is ambiguous, and the truth of literature appears in the twilight. This ambiguity of beauty, which extends Baumgarten's literary epistemology into metaphysics, depends on the concept phaenomenon. In his analysis of perfection and different lighting conditions, his attention repeatedly turns to the materiality of literature. For the path, or rather the detour, to beauty always has to go through the sheer material of signification. Every rhetorical figure or trope clothes (vestire) a representation as if with a fabric (see AE $\S 565$ ), which he seems to think of less as a beautifully falling garment than as a veritable web. On the basis of this radical materialization of beauty, of all the great nineteenth-century works on aesthetics, only Hegel can really be compared with Baumgarten. When Hegel defines art in his Vorlesungen über die Ästhetik as a form of consciously interpreting the world through a representation whose task is to make truth evident, he emphasizes precisely the materiality of art that is so central in Baumgarten. His aesthetics thus points toward the future of a consolidating modernity. ${ }^{57}$ Paying attention to the fact that literature always appears in the materiality of its signs, he invents the first metaphysics of media; in Baumgarten's articulation, it is not a general metaphysics of media but rather a metaphysics of literature.

With the concept phaenomenon, Baumgarten is concerned with how only something "that is a phenomenon (§ 14)" (AE § 18; qui phaenomenon sit, §. 14) can be beautiful. He first establishes the dependence of beauty on phenomenality in his Metaphysica. ${ }^{58}$ In paragraph 662 - which he refers to in paragraphs 14 and 18 of the Aesthetica, the central paragraphs on beauty in that work - he defines beauty as follows: "The perfection that is a phenomenon <perfectio phae-

56 Christoph Bode, "The Aesthetics of Ambiguity," in Actas del XII Congreso Nacional de la Asociación Española de Estudios Anglo-Norteamericanos: Alicante, 19-22 de Diciembre de 1988 (Granada: AEDEAN, 1991), 79.

57 See Scheer, Einführung in die philosophische Ästhetik, 123.

58 See Franke, Kunst als Erkenntnis, 76-116; Schweizer, Ästhetik als Philosophie der sinnlichen Erkenntnis, 40 -81; Paetzold, Ästhetik des deutschen Idealismus, 35-42; Groß, Felix aestheticus, 143-162. 
nomenon>, or the perfection observable by taste in the broader sense, is BEAUTY, whereas the imperfection that is a phenomenon <imperfectio phaenomenon>, or the imperfection observable by taste in the broader sense, is UGLINESS" (MET $\S$ 662; Perfectio phaenomenon, s. gustui latius dicto observabilis, est PULCRITUDO, imperfectio phaenomenon, seu gustui latius dicto observabilis, est DEFORMITAS).

With regard to literature, it is obvious that perfection becomes a phenomenon on the material surface of the literary text. In the rhetorical canon of inventio, Baumgarten differentiates the beauty of things from that of thoughts (pulcritudo rerum et cogitationum); in the canon of dispositio, he finds the beauty of order (pulcritudo ordinis), and in the canon of elocutio, that of the means of expression (pulcritudo significationis). These three types of beauty all also consist in perfection (see $\mathrm{AE} \S \S 18-24$ ). On the material surfaces of literary texts, they thus appear in figures of thought (figurae sententiae), figures of order (figurae ordinis), and figures of speech (figurae significationis, figurae dictionis; see $\mathrm{AE} \S 26$ ), which now have to be taken seriously in their materiality and also with regard to their metaphysical aspects. While concepts, which can be represented in logical formulas, are completely available to human reason, Baumgarten devalues them in comparison to phenomena:

For my part, I believe it is entirely apparent to philosophers that whatever particular formal perfection is present in cognition and logical truth can only have been acquired with the loss of much and great material perfection. For what is abstraction if not a loss?

Equi[d]em arbitror philosophis apertissimum esse iam posse, cum iactura multae magnaeque perfectionis in cognitione et veritate logica materialis emendum fuisse, quicquid ipsi perfectionis formalis inest praecipuae. Quid enim est abstractio, si iactura non est? (AE $\S 560$; see also AE §562)

In the second half of the eighteenth century, aesthetics actually limits itself to the question of representations of the beautiful, whereas beautiful representations as such, either in the acoustic medium of the voice or the graphic medium of the text, are ignored. In his analysis of the structure of literary discourse, Baumgarten turns attention to precisely this question..$^{59}$ Almost simultaneously, Henry Home's Elements of Criticism (1762) articulates the preconditions for debating the relation between materiality and beauty, preconditions that apply both to William Hogarth's Analysis of Beauty (1753) and Johann Joachim Winckelmann's art-theoretical writings from the 1760s: "The term beauty, in its native signification, is appropriated to objects of sight. Objects of the other senses may be agree-

59 See 3.3 Semiotics. 
able, such as the sounds of musical instruments, the smoothness and softness of some surfaces: but the agreeableness denominated beauty belongs to objects of sight." 60 In this context, there are only two possibilities for literature to be beautiful: it is either related, in the context of crude illusionism, to the paradigm of mimesis - in which case, it is not the arbitrary signs that are beautiful but rather the image of the world that literature imitates and simulates, possibly better than the natural signs of the visual arts can - or literature is regarded for its own manifest beauty, which is based on the specific sensation of acoustic and graphic media. In the 1760s, however, when Lessing and Denis Diderot laid the groundwork for semiotic aesthetics, this second possibility did not come into consideration.

To analyze the capacity of literature and visual arts to simulate beauty, Lessing and Diderot turn their attention to the different forms of intuition of the two media. The bottom line of the examination is, contrary to traditional poetics, their incompatibility: poetry is unlike a picture - ut pictura poesis non erit, as Diderot formulates the new anti-Horatian phrase in his response to the 1767 Salon. ${ }^{61}$ For the non of this analogy, Lessing proposes the two well-known medial passe-partouts: the temporal successiveness of language and the spatial simultaneity of the image. Based on them, he evaluates each medium's suitability for representing the beautiful and finds, as Joachim Jacob summarizes, that "the beautiful is 'uncomfortable' for a linguistic representation that develops in the course of discourse" because it "is a quality of an object that is only adequately disclosed to a simultaneous visual impression." 62 According to Lessing, the prudent poet "abstains entirely from the depiction of physical beauty as such," since "the concentrating glance which we try to cast back on the parts after they have been enumerated fails to produce the effect of a harmonious image."63

With such arguments, eighteenth-century media aesthetics is subject to the tyranny of mimesis. The possibility of literary beauty - of a beauty of literature suffers under this subjugation; ${ }^{64}$ paintings and sculptures are beautiful in this sense, not texts. The concept of representation (Darstellung) thus serves as an

60 Henry Home (Lord Kames), Elements of Criticism, vol. 1 (Edinburgh, 1762; facsimile, Hildesheim: Georg Olms, 1970), 242-243.

61 See Denis Diderot, Salons, ed. Jean Seznec and Jean Adhémar, vol. 3, 1767 (Oxford: Oxford University Press, 1963), 108.

62 Jacob, Die Schönheit der Literatur, 187.

63 Gotthold Ephraim Lessing, Laocoön: An Essay on the Limits of Painting and Poetry, trans. Edward Allen McCormick (Baltimore: Johns Hopkins University Press, 1984), 104.

64 See 5.3.2 Probability. 
"index and medium of an upheaval in the history of theory." ${ }^{65}$ Baumgarten, Lessing, and Herder use this concept to critique aesthetic illusion when they begin to consider the nonintuitive remainder of language. With language, the "new structure" of a linguistically mediated "imaginative synthesis" prevails in "thoroughly obscure sequences" 66 - a structure that is itself medially realized since it combines what Lessing separates into the spatial form of intuiting texts and the temporal form of intuiting voices. ${ }^{67}$

By approaching literature with a metaphysics of media, Baumgarten positions himself somewhat askew to the discourses dominating the second half of the eighteenth century. His engagement with the structure of literary discourse and its functions of complexity, opacity, and performativity anticipates many arguments that formalism and phenomenology will use to turn attention to the medium of literature. Because he decouples beauty from vision and visuality, ${ }^{68}$ beauty appears in the linguistic form itself: in letters, in conceptualized sounds recalled by letters, and, above all, in the combination of signs, words, and sentences that forms the graphic medium of the text as a whole.

Baumgarten even supplies the beauty of literature with an index of movement. Whereas Winckelmann tries once again to tie beauty, equanimity, and morality together in a single package, the categories of energy and life are at the center of reception aesthetics in the second half of the eighteenth century, which undergoes a paradigm change from docere to movere. As Jacob explains, "This leads to the consequence of either, as Lessing demonstrates, charging the beautiful with movement, or, following Edmund Burke's example, placing it as 'calm beauty' - which is usually devalued in its aesthetic valence - in opposition to an 'animate sublime." ${ }^{69}$ It is not by accident that Lessing sets beauty in motion using a concept that aesthetics shares with nascent neurophysiology. "Stimulus [Reiz] is beauty in motion,"70 as Lessing defines the media-specific beauty of literature, ${ }^{71}$ a beauty that implements the impulses of movement as if they were triggered by electrodes in a muscle.

This definition of a specifically literary beauty falls, however, far behind Baumgarten's. When he considers the general conditions of beauty at the inter-

65 Menninghaus, "Darstellung," 205.

66 Inka Mülder-Bach, Im Zeichen Pygmalions: Das Modell der Statue und die Entdeckung der "Darstellung" im 18. Jahrhundert (Munich: Wilhelm Fink, 1998), 142.

67 See 3.3 Semiotics.

68 See 4.1.1 Perfection.

69 Jacob, Die Schönheit der Literatur, 259.

70 Lessing, Laocoön, 112, translation modified. See 4.1.1 Perfection.

71 See Jacob, Die Schönheit der Literatur, 242. 
face with the sublime, he defines all beauty as always and necessarily animate. ${ }^{72}$ And he aims to provide the animate beauty of the performative literary text with a mythology when he calls aesthetics the "philosophy of the Muses and Graces" (KOLL § 1; Philosophie der Musen und der Grazien). He may have been familiar with the concept of grace in English aesthetics. For example, Hogarth's articulation of grace bears a resemblance to Baumgarten's performativity, the third function of the structure of literary discourse - that is, the sensate will that sets literature in motion and is compared to a dancer's elegant movements. ${ }^{73}$ For Hogarth, the "line of grace" is, as Jacob explains, even superior to the "line of beauty." This is because the line of grace "adds a further dimension to the beautiful in technique and, reaching far into the depths, is able to unite a variety to an even greater extent. For the painter Hogarth, beauty and grace are thus decidedly painterly and sculptural categories, categories that relate to one another according to the measure of complexity that is represented or made visible."74 Baumgarten realizes this possibility of translating grace from the visual arts into literature, a possibility that is offered above all by Home, who notes that both dance and public speaking can show grace: "Dancing affords great opportunity for displaying grace, and haranguing still more."75

In sum, beauty can never escape the two media of literature, text and voice. ${ }^{76}$ Baumgarten therefore not only reflects on the metaphysics of phenomenal particularity but also on this metaphysics as a metaphysics of literature. Differently from Meier, for whom media are merely "channels [...] through which beautiful thoughts flow out of one beautiful spirit and into another"77 - and so also differently from the practice of suppressing or denying the materiality of the medium or regulating it through fetishization in the age of sensibility (Empfindsamkeit) Baumgarten brings media into the horizon of theoretical reflection. ${ }^{78}$ Considering that even Lessing "foregoes formulating a concept of beauty tuned to the requirements of the poetic medium," "79 Baumgarten's model of the beautiful text is truly something new.

72 See 4.1.1 Perfection.

73 See 3.4.3 Performativity.

74 Jacob, Die Schönheit der Literatur, 263.

75 Home, Elements of Criticism, 1:348.

76 See 3.3 Semiotics.

77 Meier, Anfangsgründe aller schönen Wissenschaften, § 711.

78 See Karlheinz Stierle, "Das bequeme Verhältnis: Lessings Laokoon und die Entdeckung des ästhetischen Mediums,” in Das Laokoon-Projekt: Pläne einer semiotischen Ästhetik, ed. Gunter Gebauer (Stuttgart: J. B. Metzler, 1984), 23-24.

79 Jacob, Die Schönheit der Literatur, 254. 


\subsubsection{Formlessness}

In the course of metaphysically legitimizing materiality in the sections on aesthetic truth (veritas aesthetica), something epistemologically exciting happens. There Baumgarten becomes stuck on the example of an unhewn marble block (see $\mathrm{AE} \S 560$ ), an example that he hopes will help elevate the standing of phenomena in comparison to concepts. At this point in the text, he has already shown how examples themselves are an excellent example of literariness. ${ }^{80}$ Searching for the role of materiality in his media metaphysics of literature, he turns to an example to capture what cannot be philosophically expressed in a concept or even with the help of metaphors. What the marble block accomplishes is simple to explain: Baumgarten has to think about a real object because this thinking helps him on his way to exciting insights. He then projects his insights about the marble block onto the concept of aesthetic truth. Through this projection, his statements about objective, real, material truth apply to aesthetic truth, which is by definition a subjective truth. Thus, to a certain extent, the phenomenon models aesthetic cognition, and Baumgarten finally interfolds metaphysica obiectiva and subiectiva into the twofold nature of beauty.

It is not without reason that Baumgarten chooses - as many others do after him - sculpture as the reference medium for beauty, though he does not commit to the human body as the symbolic intuition of perfection as Winckelmann, Herder, Karl Philipp Moritz, and Johann Wolfgang Goethe later do. ${ }^{81}$ And when Baumgarten interprets the example of the unhewn marble block semiotically, he also does not fix the sign to the (partial) correspondence of shape and meaning (see $\mathrm{AE} \S 561$ ) as it is later formulated with the concept of the intuitive symbol (Anschauungssymbol) in the Goethezeit. Instead, the marble block generates its meaning on the basis of its own wealth of relations, and the material excess of this wealth is beautiful: "By similar reasoning, one cannot produce a marble globe out of irregularly shaped marble, at least not without such a loss of material that the price of roundness will be quite high" (AE $\S 560$; Pari ratione ex marmore irregularis figurae non efficias globum marmoreum, nisi cum tanto saltim materiae detrimento, quantum postulabit maius rotunditatis pretium). The unhewn marble block does not have any form corresponding to a geometric concept. In its fragmentariness, it nevertheless proves to be more beautiful, and thus more perfect and more true, than the sphere. In the unhewn

80 See 2.2 Analogy. See also Frauke Berndt, “Rock Sample: Alexander Gottlieb Baumgarten,” in Aesthetic Theory, ed. Dieter Mersch, Sylvia Sasse, and Sandro Zanetti, trans. Brian Alkire (Zurich: Diaphanes, 2019), 21-35.

81 See Mülder-Bach, Im Zeichen Pygmalions, 20-48. 
stone, Baumgarten does not want to round off anything or bring anything into a form even if the sublimity of the phenomenon that arises from this abstention exceeds the human powers of comprehension. That is exactly why the marble block is an example of aesthetic truth (veritas aesthetica).

Both Mirbach and Johannes Hees have pointed out that Baumgarten's search for aesthetic truth draws on Leibniz's ontological concept of individuality. ${ }^{82}$ In his introduction to the German translation of Leibniz's Nouveaux essais sur l'entendement humain (1765; written between 1703 and 1705), Cassirer notes:

But according to the fundamental principle that Leibnizian metaphysics expresses and undertakes in full clarity for the first time, the character of the real lies in its thorough individuality. [...] For if pure mathematical space is characterized by its total uniformity, then matter is characterized by its thorough dissimilarity. Here in real being and happening, there are no two elements that are completely similar, no two movements that are identical to one another in all their individual phases. There are only the "same parts" in an abstraction that can arbitrarily disregard certain differing moments; not in reality, whose particularity goes on infinitely. But how can this boundless manifold of reality be merged with the demand for unity that lies in our understanding; how can the universality of rules and laws grasp the individual, in which "being" originally and actually consists? ${ }^{83}$

To deal with these metaphysical problems, Leibniz also employs a comparison with an unhewn marble block in the Nouveaux essais, a comparison that Baumgarten doubtlessly takes from him while making, however, decisive corrections. For Leibniz, the marble illustrates the philosophical problem of innate ideas:

I have also used the analogy of a veined block of marble, as opposed to an entirely homogeneous block of marble, or to a blank tablet - what the philosophers call a tabula rasa. For if the soul were like such a blank tablet then truths would be in us as the shape of Hercules is in a piece of marble when the marble is entirely neutral as to whether it assumes this shape or some other. However, if there were veins in the block which marked out the shape of Hercules rather than other shapes, then that block would be more determined to that shape and Hercules would be innate in it, in a way, even though labour would

82 See Dagmar Mirbach, "Einführung zur fragmentarischen Ganzheit von Alexander Gottlieb Baumgartens Aesthetica (1750/58),” in Mirbach, ed. Ästhetik by Alexander Gottlieb Baumgarten, trans. Mirbach, vol. 1 (Hamburg: Felix Meiner, 2007), xv-lxxx; Johannes Hees, "Denken und Betrachten: Zur Proto-Ästhetik bei Gottfried Wilhelm Leibniz und Barthold Hinrich Brockes,” Zeitschrift für Ästhetik und Allgemeine Kunstwissenschaft 64.1 (2019): 87-109.

83 Ernst Cassirer, "Einleitung," in Neue Abhandlungen über den menschlichen Verstand, by Gottfried Wilhelm Leibniz, trans. Cassirer, vol. 3 of Philosophische Werke, ed. Cassirer (Hamburg: Felix Meiner, 1996), xxiv-xxv. 
be required to expose the veins and to polish them into clarity, removing everything that prevents their being seen. This is how ideas and truths are innate in us. ${ }^{84}$

With the example of the marble block, Baumgarten is not interested in the problem of innate ideas. He is interested, rather, in its marbled materiality as such; or, more provocatively, he is interested in the real - the material remainder that constitutes objective, real, material truth (veritas realis, materialis). And with precisely this marble block, he switches from discussing subjective truth to discussing objective truth. This switch, which is a philosophical no-go, proves to be key to this theory of literature. For in Baumgarten's metaphysics of beauty, the beautiful is the material or the real in the sense of Jacques Lacan, who makes, as I have summarized elsewhere, exactly the same movement between the subject and the object when he defines the real: "It [the real] forms, with the imaginary and the symbolic, the third position in the triad that constitutes the foundation of Lacanian psychoanalysis. Like the other two concepts, the real also refers to a psychic structure; but in relation to the imaginary and the symbolic, it does not represent a mere remainder even though it is incomprehensible, unthinkable, impossible, and, above all, unsayable. Instead, Lacan defines the real as something that eludes symbolization (and imagination), indeed, as something that represents a resistance to the symbolic and, to a certain extent, a cut in the symbolic." ${ }^{85}$ Baumgarten thus uses the example of the marble block to conceive the real of the literary text, that is, its phenomenality, which confronts him with the materially incommensurable remainder of literature.

When one considers the role of the marble block in discussing subjective truth and the role of aesthetics in aestheticological truth, it becomes clear that this example will have to stage the confrontation with the real as something overwhelming. In fact, Baumgarten does trace how the subject is overtaxed by the object's sheer materiality. In his own argumentation, this inundation is expressed in a series of further examples, which again reflects his lack of concepts for the problem he wants to describe. Instead of a single philosophical concept, he cites three concepts that the Aristotelian tradition uses to refer to formless matter: forest, Chaos, and matter (silva, Chao, et materia). He then returns to the example of the marble block when he investigates working on the material, the sculptor's work with his tools on the marble. In contrast to Leibniz's interpretation, however, a human torso like Hercules does not appear out of the marble;

84 Gottfried Wilhelm Leibniz, New Essays on Human Understanding, ed. and trans. Peter Remnant and Jonathan Bennett (Cambridge: Cambridge University Press, 1996), para. 52.

85 Frauke Berndt, “Das Reale,” in Handbuch Literatur \& Psychoanalyse, ed. Berndt and Eckart Goebel (Berlin: Walter de Gruyter, 2017), 638. 
instead, as little material as possible is to be lost. Baumgarten is concerned with the apotheosis of formlessness, not with form - neither with geometric spheres nor with classical sculpture. If, indeed, he is concerned with Hercules, then he is interested in the destroyed, formless parts of a statue, just as Winckelmann is fascinated by the fragmentariness of the Belvedere Torso, in whose formlessness he imagines the presence of the actual mythological god in his Beschreibung des Torso im Belvedere zu Rom (1755): ${ }^{86}$

The aesthetic horizon especially delights, however, in the singular, individual, and most determined things exhibiting the greatest material perfection of aestheticological truth, in its forest, Chaos, and matter (§ 129), out of which it sculpts aesthetic truth into a form that is, if not perfect, nevertheless beautiful $(\S \S 558,14)$ such that while it is being worked, as little materially perfected truth as possible may be lost and, for the sake of elegance, be rubbed away by its own power (§ 563).

praesertim autem perfectionem materialem veritatis aestheticologicae maximam exhibentibus singularibus, individuis, et determinatissimis fruitur horizon aestheticus, sua silva, Chao, et materia, §. 129. ex quibus veritatem aestheticam ad formam, nisi perfectam omnino, pulcram tamen, §. 558, 14. ita exsculpat, ut inter elaborandum, quam fieri potest minimum veritatis materialiter perfectae pereat et elegantiae caussa pollendo deteratur, §. 563 . (AE § 564)

With the comparisons, Baumgarten also draws a line back to the philosophical concepts he uses to define the example - to singular, particular, and most-determined objects. This exceptional and thus thoroughly modern truth only applies to them. It is this truth that is visually and affectively evident, that both stands before the eyes and touches and moves us.

When Baumgarten wants to describe the role of aesthetics in aestheticological truth, the role that the example plays in his literary epistemology changes. In the Meditationes, the example is an example of literature, or rather of literariness. The objects of his observations and descriptions are single examples, such as Horace's first ode or the catalogue of ships in the second canto of Homer's Iliad (see MED §§19-20), but these examples are, to a certain extent, only examples of the example itself; and the example itself is, in turn, an example of what literature is; and literature is itself, finally, an example of aesthetic cognition. Baumgarten therefore treats examples in the Aesthetica because, first,

86 See Frauke Berndt, "Ex marmore: Evidenz im Ungeformten bei J. J. Winckelmann und A. G. Baumgarten,” in Präsenz und Evidenz fremder Dinge im Europa des 18. Jahrhunderts, ed. Birgit Neumann (Göttingen: Wallstein, 2015), 73-96; Ralf Simon, "Petites perceptions und ästhetische Form," in Leibniz in Philosophie und Literatur um 1800, ed. Wenchao Li and Monika Meier (Hildesheim: Georg Olms, 2016), 210-212. 
the analogon of reason can only grasp aesthetic truth sensately, that is, through examples. And, second, he uses them - for better or worse - at the crucial point on aesthetic truth (veritas aesthetica), which starts with a series: the marble block, the forest, Chaos, and matter are not merely deployed where knowledge is lacking or too complex but rather where knowledge no longer has a propositional form at all.

This discovery of a new aesthetic truth that is precisely not analogous to logical truth drives Baumgarten to switch within his own discourse from a conceptual mode to a literary one. It is in this moment, in using examples, that the philosopher himself becomes a poet. For the creative poet can do something that the strict philosopher does not even dare to dream of: he simply transfers real or material truth from the position of the object (veritas obiectiva) in his philosophical system to the position of the subject (veritas subiectiva). There, real or material truth organizes Baumgarten's concept of aesthetic truth. The example thus does not illustrate aesthetic truth. Instead, the marble block develops a "dynamic of displacement" that he condenses into a series of metonymies: "silva, Chao, et materia." As an etymological "trope that displaces borders," ${ }^{87}$ metonymy thereby accomplishes exactly what the conceptual work of philosophy is incapable of accomplishing. Baumgarten etymologically displaces the border between premodern and modern knowledge - as well as between conceptual and nondiscursive knowledge - just enough for the new concept of aesthetic truth to be inserted into the eighteenth-century order of knowledge, and he condenses this new concept in a series of examples since he lacks other concepts to explain it.

By doing so, he also separates - I would say irrevocably - similarity from the epistemology of the exemplary. The marble block, the forest, Chaos, and matter are neither similar nor dissimilar nor opposite to aesthetic truth. Baumgarten does not ground his analogy ontologically like Leibniz, nor does he anchor it ethically in the archive of things that have been held to be similar. In the literary mode, examples attain autonomy. The marble block, the forest, Chaos, and matter are not analogies for aesthetic truth because they produce a semantic relation between a particular and another particular but rather because, in their formlessness, they embody the nondiscursivity of aesthetic truth in a structurally analogous way. The example is thereby the relay between the episteme of representation and the episteme of presence. With this structural analogy, Baumgarten's literary epistemology does not, of course, collapse in a logical paradox that does not allow any differentiation between embodiment and the embodied.

87 Wolfram Groddeck, Reden über Rhetorik: Zu einer Stilistik des Lesens (Frankfurt am Main: Stroemfeld, 1995), 234. 
Instead, his analogy drifts metonymically in the direction of the never-reachable vanishing point of aesthetic truth: beauty. And again, this dynamic requires that sensate desire be considered both in epistemology ${ }^{88}$ - where it primarily appears as the performativity of the structure of literary discourse $\mathrm{e}^{89}$ - and in metaphysics. ${ }^{90}$

In the Aesthetica, Baumgarten copes with this philosophical crisis, which literally leaves him speechless, by inserting an epistemologically exciting break in the argumentation: namely, he suddenly returns from metaphysics to rhetoric. According to Baumgarten's summation of his theoretical experiment, literature cannot actually be true at all in a philosophical sense - neither objectively nor subjectively, neither logically nor aesthetically - and the whole metaphysics of beauty was just a waste of time. Literature - this is his conclusion - cannot claim any kind of truth but rather only truth-likeness. That is the crux that Baumgarten attends to in section 29 on aesthetic verisimilitude (verisimilitudo aesthetica). Precisely this rhetorical concept takes him to a new field of literary theory the theory of poetic fiction. ${ }^{91}$

88 See 3.1.2 Desire.

89 See 3.4.3 Performativity.

90 See 4.1.1 Perfection.

91 See 5.3.2 Probability. 